\title{
Single-cell physiological structure and growth rates of heterotrophic bacteria in a temperate estuary (Waquoit Bay, Massachusetts)
}

\author{
Xosé Anxelu G. Morán,a,b,* Hugh W. Ducklow, ${ }^{\mathrm{b}}$ and Matthew Erickson ${ }^{\mathrm{b}}$ \\ a Instituto Español de Oceanografía, Centro Oceanográfico de Xixón, Xixón, Asturies, Spain \\ b The Ecosystems Center, Marine Biological Laboratory, Woods Hole, Massachusetts
}

\begin{abstract}
Flow cytometric determinations of membrane integrity, nucleic acid content, and respiratory activity were combined with dilution cultures in Waquoit Bay Estuary (Massachusetts) to estimate specific growth rates of total, live, high (HNA), and low (LNA) nucleic acid content and actively respiring (CTC+) cells. Bacterial abundance ranged from $10^{6}$ to $10^{7}$ cells $\mathrm{mL}^{-1}$, with live cells generally contributing $>85 \%$ to total numbers, 42 $82 \%$ HNA cells, and 3-36\% CTC+ cells. Specific growth rates $(\mu)$ from all physiological groups were positively correlated, but they showed different temperature dependences, with activation energies ranging from 0.28 (live) to $0.97 \mathrm{eV}$ (LNA). The $\mu$ values of live cells $\left(0.14-2.40 \mathrm{~d}^{-1}\right)$ were similar to those of total bacteria $\left(0.06-1.53 \mathrm{~d}^{-1}\right)$. LNA bacteria were not dormant but showed positive growth in most experiments, although HNA cells greatly outgrew LNA cells ( $\mu$ ranges of $0.28-2.26 \mathrm{~d}^{-1}$ vs. $\left.0-0.69 \mathrm{~d}^{-1}\right)$, and CTC+ cells showed the highest values $(0.12-$ $\left.2.65 \mathrm{~d}^{-1}\right)$. Positive correlations of HNA bacteria $\mu$ with total and phytoplankton-derived dissolved organic carbon support the previously hypothesized strong bottom-up control of HNA cells. Bacterial production estimated from leucine incorporation and empirical conversion factors agreed well with estimates based on growth rates. HNA cells were always responsible for the largest share of bacterial production in the estuary. The contribution of CTC+ cells significantly increased with temperature in the $7-27^{\circ} \mathrm{C}$ range, reaching values of $40 \%$ at temperatures higher than $20^{\circ} \mathrm{C}$.
\end{abstract}

Planktonic heterotrophic bacteria are frequently considered as a single ecological compartment due to their major shared role in the uptake and remineralization of dissolved organic matter. However, heterotrophic prokaryotes are highly diverse both phylogenetically and physiologically (Comte and Del Giorgio 2009). Individual activity probes have allowed the recognition of cells characterized by distinct metabolic properties or levels of activity (Smith and Del Giorgio 2003). The term physiological structure of bacterial communities (Del Giorgio and Gasol 2008) has been recentlty proposed for the distribution of cells into operational categories of metabolic properties and activity, including membrane integrity and polarity, nucleic acid content, and respiratory activity.

Bacterial assemblages are composed of a few more rapidly growing members and a usually larger number of cells with slower growth (Ducklow et al. 1999; Gasol et al. 1999) distributed along a continuum of many possible intermediate states (Smith and Del Giorgio 2003). However, these different subgroups have seldom been specifically characterized. Commonly, the evolution of only the total number of cells in dilution culture regrowth experiments (Ducklow 2000) is monitored for estimating mean specific growth rates $(\mu)$ of the whole assemblage. Until the advent of flow cytometry, enumeration of cells was time consuming, and many reports of bacterioplankton $\mu$ relied on concurrent estimates of bacterial production (BP) and biomass (BB), in which $\mu$ was calculated simply as $\mathrm{BP}: \mathrm{BB}$ ratios (Kirchman 2002). One shortcoming of this approach is the necessity of assuming or deriving conversion factors (Ducklow 2000), which have been shown to vary widely

\footnotetext{
* Corresponding author: xelu.moran@gi.ieo.es
}

both for biomass (7-53 fg C cell ${ }^{-1}$; Ducklow 2000) and production $(<0.5-3.6 \mathrm{~kg} \mathrm{C} \text { [mol Leu }]^{-1}$; Alonso-Sáez et al. 2008; Calvo-Díaz and Morán 2009).

By affecting the rate of enzymatic reactions, temperature has been frequently shown to be a major factor regulating bacterial biomass, production, and growth rates (White et al. 1991; Kirchman et al. 2009; Ducklow et al. 2010). However, the frequent covariation of temperature with substrate availability over wide temperature ranges (i.e., warm waters are usually nutrient deficient in many pelagic ecosystems) renders it difficult to describe the true temperature dependence of bacterial growth rates. Persistently eutrophic ecosystems, such as urban coastal areas or estuaries, are excellent environments for testing the direct effect of temperature on bulk and group-specific bacterial growth rates and standing stocks because limitation by resources would be nonexistent year-round (Feuerpfeil et al. 2004). In contrast, in systems where inorganic and/or organic nutrients become limiting during summer, the temperature dependence of bacterial metabolism is greatly dimished or lost above some threshold value (Hoch and Kirchman 1993; Shiah and Ducklow 1994b; A. Calvo-Díaz and X. A. G. Morán unpubl.).

As with phylogenetic groups (Fuchs et al. 2000; Yokokawa et al. 2004; Teira et al. 2009), specific growth rates would also be expected to differ among distinct physiological groups, but so far, not many studies have compared the cell-specific activity of more than two groups simultaneously (Gasol et al. 1999; Longnecker et al. 2005; Jost et al. 2008), and $\mu$ values are rarely reported (Del Giorgio et al. 1996; Gasol et al. 1999). Three single-cell physiological probes, separating live and dead (Grégori et al. 2001), low (LNA) and high (HNA) nucleic acid content 
(Li et al. 1995; Bouvier et al. 2007) and actively respiring (CTC+) bacterial cells (Sherr et al. 1999), varied consistently throughout the year in temperate eastern North Atlantic waters, with distinct periods in their contribution to total numbers and relationships with environmental factors (Morán and Calvo-Díaz 2009). Although live cells are usually more abundant than dead ones (Lamy et al. 2006), there is considerable variability among systems (Schumann et al. 2003). Other studies have specifically suggested that HNA bacteria apparently depend more than LNA bacteria on phytoplankton substrates for growth and metabolism (Li et al. 1995; Morán et al. 2007; Scharek and Latasa 2007). Despite their usually lower contribution to abundance $(<20 \%)$, CTC + cells play a substantial part in bulk bacterial activity and production (Lovejoy et al. 1996; Smith 1998; Morán and Calvo-Díaz 2009).

The three aforementioned single-cell probes were used to obtain information about the physiological status of estuarine bacterial assemblages in Waquoit Bay (Massachusetts) over a temperature range of $7^{\circ} \mathrm{C}$ to $27^{\circ} \mathrm{C}$. Sampling from May through December in three different subestuaries and nearby coastal waters was intended to provide multiple observations over a wide range of environmental conditions. We estimated the relative importance of live, LNA, HNA, and CTC+ bacteria, and calculated the specific growth rates of these four fractions in a total of 24 dilution experiments. The aim of this study was to assess whether the different single-cell groups were consistently characterized by different $\mu$ and to ascertain the environmental drivers that determined the physiological responses. Correlation and regression analyses were used to evaluate the importance of individual factors. Two hypotheses were specifically tested: that HNA cells are more dependent on phytoplankton-derived organic matter than LNA cells and that the contributions of each physiological group to total carbon flow through heterotrophic bacteria are characterized by different temperature dependences.

\section{Methods}

Study site-Waquoit Bay $\left(41^{\circ} 34^{\prime} \mathrm{N}, 70^{\circ} 31^{\prime} \mathrm{W}\right)$ receives large amounts of nutrient loading in the upper riverine reaches and is considered a mesotrophic to eutrophic estuary (Valiela et al. 1992). This estuary presents different subestuaries characterized by dissimilar nitrogen loadings due to different land uses and comparatively pristine areas coexisting with densely populated subwatersheds, and therefore it offers a wide range of environmental conditions at a single, easily accesible site (Valiela et al. 1992). During 2008, we conducted a comprehensive assessment of bacterioplankton standing stocks and production rates in three subbasins: Childs River (CR), Quashnet River (QR), and Sage Lot Pond (SL), plus coastal waters in Nantucket Sound outside the Waquoit Bay entrance canal (NS).

Experimental setup-Dilution regrowth experiments were performed with surface water sampled from a small boat. Within $1 \mathrm{~h}$ from collection, $400 \mathrm{~mL}$ of water were diluted with $1600 \mathrm{~mL}$ of $0.2-\mu \mathrm{m}$-filtered (polycarbonate, 47 - $\mathrm{mm}$ diameter) water from the same site. These water samples were incubated in the dark at in situ temperature in temperature-controlled chambers. After stirring, samples for bacterial abundance and production were taken twice per day during the first $2 \mathrm{~d}$, and one to two additional samples were taken daily for determination of the exponential phase of growth.

Environmental properties-Salinity, temperature, and oxygen were measured with a Yellow Springs Instrument portable sensor (YSI 85 model). Inorganic nutrients (phosphate, nitrate + nitrite, and silicate) samples were filtered on-site and measured on a Lachat Quikchem FIA+ 8000 Series. Chlorophyll a (Chl $a)$ concentration was measured fluorometrically in a Turner 10-AU fluorometer after overnight extraction in $90 \%$ acetone of pigments recovered onto Whatman GF/F filters from $50-100-\mathrm{mL}$ samples. Dissolved organic carbon (DOC) and dissolved organic nitrogen $(\mathrm{DON})$ concentrations $\left(\mu \mathrm{mol} \mathrm{L}^{-1}\right)$ were determined with a Shimadzu total organic carbon and nitrogen analyzer (TOC-V/TN). Aliquots $(60 \mathrm{~mL})$ were taken on-site and kept frozen at $-20^{\circ} \mathrm{C}$ until analysis.

Single-cell physiological groups-Membrane-intact (live) and membrane-damaged (dead) bacterial cells were distinguished by a nucleic acid double-staining protocol with propidium iodine (PI) and SYBR-Green (Grégori et al. 2001). Cells with low (LNA) and high (HNA) nucleic acid content ( $\mathrm{Li}$ et al. 1995) were distinguished after SYBRGreen staining of $0.4 \mathrm{~mL}$ of thawed samples. Actively respiring (CTC + ) cells were identified as those capable of reducing 5-cyano-2,3-ditolyl tetrazolium chloride (CTC; Rodriguez et al. 1992). Details on the specific protocols used are described in Morán and Calvo-Díaz (2009). A benchtop fluorescence activated cell sorter flow cytometer (FACSCalibur, Becton Dickinson) was used for all singlecell group enumerations.

Bacterial biomass and production - Total bacterial abundance was estimated as the sum of LNA and HNA cell numbers. Bacterial biovolume $\left(\mu \mathrm{m}^{3}\right)$ was estimated from an empirical calibration between right-angle light scatter (RALS) and bacterial size (diameter $[\mu \mathrm{m}]=0.40+1.51$ $\times$ RALS, $r^{2}=0.87, p=0.007, n=6$ ) and carbon biomass eventually calculated as described in Calvo-Díaz and Morán (2009).

Bacterial production rates $\left(\mu \mathrm{g} \mathrm{C} \mathrm{L}^{-1} \mathrm{~d}^{-1}\right)$ was estimated from ${ }^{3} \mathrm{H}$-leucine (Leu) incorporation rates (LIR, pmol Leu $\mathrm{L}^{-1} \mathrm{~h}^{-1}$ ) (Kirchman et al. 1985) using the centrifugation method (Smith and Azam 1992) as described elsewhere (Ducklow et al. 2001). Empirical leucine to carbon conversion factors (LCF) were estimated every time at each site following Calvo-Díaz and Morán (2009). Values ranged from 0.43 to $2.05 \mathrm{~kg} \mathrm{C}[\mathrm{mol} \mathrm{Leu}]^{-1}$.

Particulate and dissolved primary production-Short incubations $(\sim 2 \mathrm{~h})$ of $65-\mathrm{mL}$ water samples spiked with ${ }^{14} \mathrm{C}$-bicarbonate $\left(3.0-3.3 \times 10^{5} \mathrm{~Bq}\right)$ were performed at the four sites in order to determine the rates of production of particulate and dissolved organic carbon by phytoplank- 
ton. Three light plus two dark replicates were incubated in sterile $25-\mathrm{cm}^{2}$ polycarbonate tissue culture flasks (Corning) under in situ temperature and saturating irradiance $\left(\sim 300 \mu \mathrm{mol}\right.$ photons $\left.\mathrm{m}^{-2} \mathrm{~s}^{-1}\right)$. At the end of the experiments, $5-\mathrm{mL}$ aliquots were taken for determination of total primary production, while the remaining $60 \mathrm{~mL}$ were filtered through $0.22-\mu \mathrm{m}$ membrane filters in order to estimate particulate (PPP) and dissolved primary production (DPP). Carbon production rates were calculated using dissolved inorganic carbon concentrations measured once at each site: 19,500 $\mu \mathrm{g} \mathrm{C} \mathrm{L}^{-1}$ for $\mathrm{CR}$ and $\mathrm{QR}, 21,000$ for $\mathrm{SL}$, and 22,000 for NS. Daily rates $\left(\mu \mathrm{g} \mathrm{C} \mathrm{L}^{-1} \mathrm{~d}^{-1}\right)$ were calculated by multiplying hourly rates by daylight hours. The contribution of dissolved primary production to total rates was expressed as percent extracellular release (PER): $100 \times \mathrm{DPP} /(\mathrm{DPP}+\mathrm{PPP})$.

Statistical analyses-Absolute abundances, concentrations, and production rates were $\log 10$ transformed in order to attain normality and homoscedasticity for subsequent correlation and regression analyses. Pearson's productmoment correlations, ordinary least squares (OLS) linear regressions, and stepwise multiple regressions were performed with STATISTICA software, version 7.1 (StaSoft).

\section{Results}

Environmental properties - Selected environmental variables and bacterioplankton abundances are shown in Table 1. Temperature increased from $\sim 16^{\circ} \mathrm{C}$ in May to $27^{\circ} \mathrm{C}$ in July-August and then decreased until December $\left(\sim 8^{\circ} \mathrm{C}\right)$. Salinity ranged from 15.4 to 31.8 , with lower values consistently observed at $\mathrm{CR}$ and $\mathrm{QR}$. Phosphate concentrations peaked in summer and early autumn $\left(\sim 0.5 \mu \mathrm{mol} \mathrm{L}^{-1}\right)$ and were usually below $0.3 \mu \mathrm{mol} \mathrm{L} \mathrm{L}^{-1}$ for the rest of the year. Chl $a$ concentrations generally followed the same pattern as temperature and phosphate with summer maxima ( $\left.>10 \mu \mathrm{g} \mathrm{L}^{-1}\right)$. DOC concentrations ranged from 95 to $346 \mu \mathrm{mol} \mathrm{L}^{-1}$ and tended to be higher in July-August, with similar, low values in May and December. The $\mathrm{C}: \mathrm{N}$ ratio of dissolved organic matter was always below 16, indicating relative nitrogen enrichment. Rates of total planktonic primary production (TPP) varied from 0.12 to $2.38 \mu \mathrm{g} \mathrm{C} \mathrm{L}^{-1} \mathrm{~d}^{-1}$, with PER values ranging from $3 \%$ to $36 \%$. TPP was strongly correlated with Chl $a(r=0.81, p<0.001, n=24)$.

Bacterial physiological structure-Total bacterial abundance (i.e., the sum of LNA and HNA cells; Table 1), displayed a consistent seasonal pattern, from $\sim 2 \times 10^{6}$ cells $\mathrm{mL}^{-1}$ in December at all sites to $>5 \times 10^{6}$ cells $\mathrm{mL}^{-1}$ in August. Live cell abundance was sometimes higher than the total, measured on preserved rather than fresh samples (Table 1), and most cells were alive (78-96\%). HNA cells usually exceeded LNA, with their contribution ranging from $42 \%$ to $82 \%$. CTC+ cells were generally one order of magnitude lower than total numbers (Table 1) and contributed between $3 \%$ and $36 \%$ to total numbers.

Temperature was strongly correlated with all single-cell group absolute abundances $(r=0.72-0.90)$, but only with

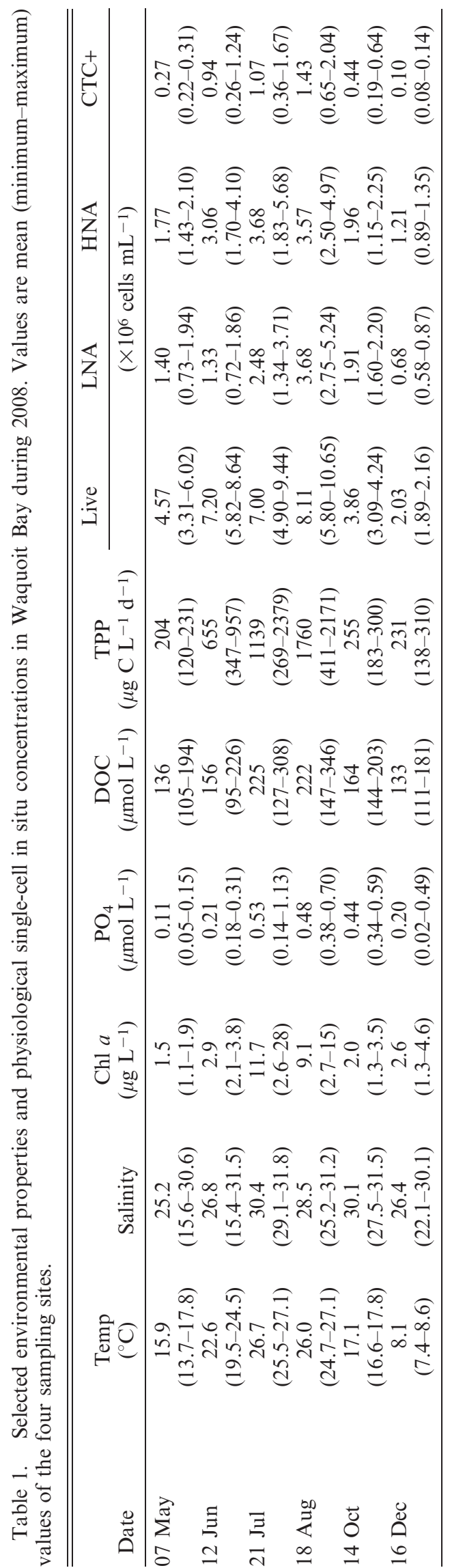


Table 2. Pearson correlation coefficients between the ambient absolute and relative abundance of total, live, LNA, HNA, and CTC+ bacteria and abiotic and biotic environmental variables in Waquoit Bay during 2008; $n=22-24$. Significant correlations are indicated in bold with the level of significance: ${ }^{*} p<0.05, * * p<0.01, * * * p<0.001$. Temp, temperature; Salt, salinity; TPP, total primary production; PPP, particulate primary production; DPP, dissolved primary production; LIR, leucine incorporation rates; BP, bacterial production.

\begin{tabular}{|c|c|c|c|c|c|c|c|c|c|c|}
\hline & Temp & Salt & DOC & $\mathrm{PO}_{4}$ & Chl $a$ & PPP & DPP & ТPP & LIR & $\mathrm{BP}$ \\
\hline Total & $0.88 * * *$ & 0.26 & $0.61 * *$ & 0.36 & $0.74 * * *$ & $0.82 * * *$ & $0.70 * * *$ & $0.82 * * *$ & $0.46^{*}$ & 0.36 \\
\hline Live & $0.90 * * *$ & 0.18 & $0.51 * *$ & 0.25 & $0.62 * *$ & $0.76 * * *$ & $0.64 * *$ & $0.76 * * *$ & $0.57 * *$ & 0.25 \\
\hline LNA & $0.72 * * *$ & $0.50 * *$ & $0.45 *$ & $0.46^{*}$ & $0.59 * *$ & $0.60 * *$ & $0.60 * *$ & $0.62 * *$ & 0.31 & $0.49 *$ \\
\hline HNA & $0.85^{* * *}$ & 0.06 & $0.66 * * *$ & 0.23 & $0.75^{* * *}$ & $0.84 * * *$ & $0.55 * *$ & $0.84 * * *$ & $0.50 *$ & $0.41 *$ \\
\hline CTC+ & $0.90 * * *$ & 0.10 & $0.71 * * *$ & 0.23 & $0.63 * *$ & $0.76 * * *$ & $0.69 * * *$ & $0.77 * * *$ & $0.56 * *$ & $0.47 *$ \\
\hline$\%$ live & -0.10 & $0.68 * * *$ & 0.12 & 0.15 & 0.01 & -0.09 & -0.05 & -0.08 & -0.28 & -0.08 \\
\hline$\%$ HNA & -0.10 & $-0.61 * *$ & 0.10 & -0.36 & 0.03 & 0.07 & -0.19 & 0.05 & 0.10 & 0.05 \\
\hline$\%$ CTC+ & $0.67 * * *$ & -0.19 & $0.65^{* *}$ & -0.04 & 0.30 & $0.48 *$ & $0.48 *$ & $0.50 *$ & $0.58 * *$ & $0.50 *$ \\
\hline
\end{tabular}

the percent contribution of CTC+ cells, while salinity was positively correlated with \% live cells and negatively correlated with \% HNA cells (Table 2). Total, particulate, and dissolved primary production and $\mathrm{Chl} a$ were also positively correlated with the abundance of all groups, but $\%$ CTC + cells was the only relative contribution bearing a significant correlation with phytoplankton production. Bacterial activity (LIR) and production (BP) were weakly associated with the abundance of HNA and CTC+ cells, as well as with \% CTC+.

Specific growth rates of physiological groups-Temporal patterns were observed for the specific growth rates of the four individual physiological fractions (Fig. 1). Ranges of variation were similar for live $\left(0.14-2.40 \mathrm{~d}^{-1}\right)$, HNA $(0.28$ $\left.2.26 \mathrm{~d}^{-1}\right)$, and CTC + cells $\left(0.12-2.65 \mathrm{~d}^{-1}\right)$, while those of LNA cells were substantially lower $\left(-0.37-0.69 \mathrm{~d}^{-1}\right)$, and growth was negative on seven occasions. Consequently, bulk specific growth rates (i.e., $\mu$ for the sum of LNA and HNA cells) were lower than any of the former three groups (range $0.06-1.53 \mathrm{~d}^{-1}$ ).

Specific growth rates of live, total, LNA, HNA, and CTC+ were positively and almost always significantly correlated (Table 3). Growth rates of HNA cells were not statistically different from those of live cells, but the $\mu$ values of both fractions were significantly lower than CTC + cells as shown by paired $t$-tests (Fig. $2 \mathrm{~B} ; t=-2.98$, df $=$ $23, p=0.01$ for HNA, and $t=-4.31$, df $=23, p<0.001$ for live). CTC + cell $\mu$ values were on average $37 \%$ and $91 \%$ higher, respectively, than HNA and live cell values. In turn, specific growth rates of HNA cells were significantly higher than those of LNA cells $(t=-6.91, \mathrm{df}=23, p \ll 0.001$; Fig. 2A).

Like abundance, specific growth rates of the four physiological groups were significantly correlated with temperature (Table 3), although they had notably lower coefficients. These apparent temperature dependences can be expressed as $Q_{10}$ or activation energies (Fig. 3). Apparent activation energies (Brown et al. 2004) were similar for total, live, HNA, and CTC+ cells $\left(E_{\mathrm{a}} 0.28-\right.$ $0.44 \mathrm{eV})$. The activation energy of LNA cells was $0.97 \mathrm{eV}$ when only positive $\mu$ values were considered. HNA cell $\mu$ values showed relatively higher correlation coefficients with bulk and phytoplanktonic production of DOC (Table 3;
Fig. 4) and were also correlated with PER $(r=0.47, p=$ $0.02, n=23$ ).

Stepwise multiple regressions yielded significant differences among groups (Table 4), with low to moderate percentages of variance explained $(38-52 \%)$. For total bacteria, $43 \%$ of the variance could be explained by a combination of DPP, DOC, and $\mathrm{PO}_{4}$ concentrations, but when the specific growth rates of LNA and HNA cells were separated, different sets of explanatory variables were included in the models. Thus, $\mu$ LNA had positive coefficients for $\mathrm{PO}_{4}$ and $\mathrm{DOC}$ and negative coefficients for mean biovolume $\left(r^{2}=0.44\right)$, whereas $\mu$ HNA was explained by DPP and DOC $\left(r^{2}=0.50\right)$. DPP was also included in the models for the specific growth rates of live and CTC+ cells, the same as bacterial biovolume, both with positive coefficients. Temperature was not included in any multiple regression.

Contribution of physiological fractions to bacterial production-Bacterial production rates derived from LIR and using empirical LCF (range 4.7-111 $\mu \mathrm{g} \mathrm{C} \mathrm{L}^{-1} \mathrm{~d}^{-1}$ ) tended to follow changes in abundance and biomass (Table 2), and they were significantly correlated with estimates based on bacterial biomass and bulk $\mu$ (range 4.4 $421 \mu \mathrm{g} \mathrm{C} \mathrm{L}^{-1} \mathrm{~d}^{-1}$; Fig. 5). The slope of the OLS regression was not significantly different from 1 ( $t$-test, $t=$ -0.22 , df $=20, p=0.83$ ), and there was no significant difference between the two sets of values (paired $t$-test, $t=$ $0.62, \mathrm{df}=22, p=0.54)$. Consequently, $\mathrm{BP}: \mathrm{BB}$ ratios were also weakly correlated with bulk $\mu$ estimates $(r=0.51, p=$ $0.015, n=22$ ), and values were not significantly different (paired $t$-test, $t=0.27, \mathrm{df}=21, p=0.79$ ).

The contribution of three mutually exclusive physiological fractions to total bacterial production was estimated from ambient abundances and the calculated group-specific $\mu$ with the following rationale. The $\%$ live cells was used to correct for an equal percentage of dead cells in both the LNA and HNA groups. CTC+ bacteria were assumed to belong to the cluster of HNA cells, since no CTC+ cells were observed within the LNA group in several experiments involving both nucleic acid fractions (Gasol and Arístegui 2007). The three groups of cells were then live LNA (1-LNA), live and non-CTC+ HNA (1-HNA), and $\mathrm{CTC}+\mathrm{HNA}$ cells $(\mathrm{CTC}+\mathrm{HNA})$. The contribution of these 

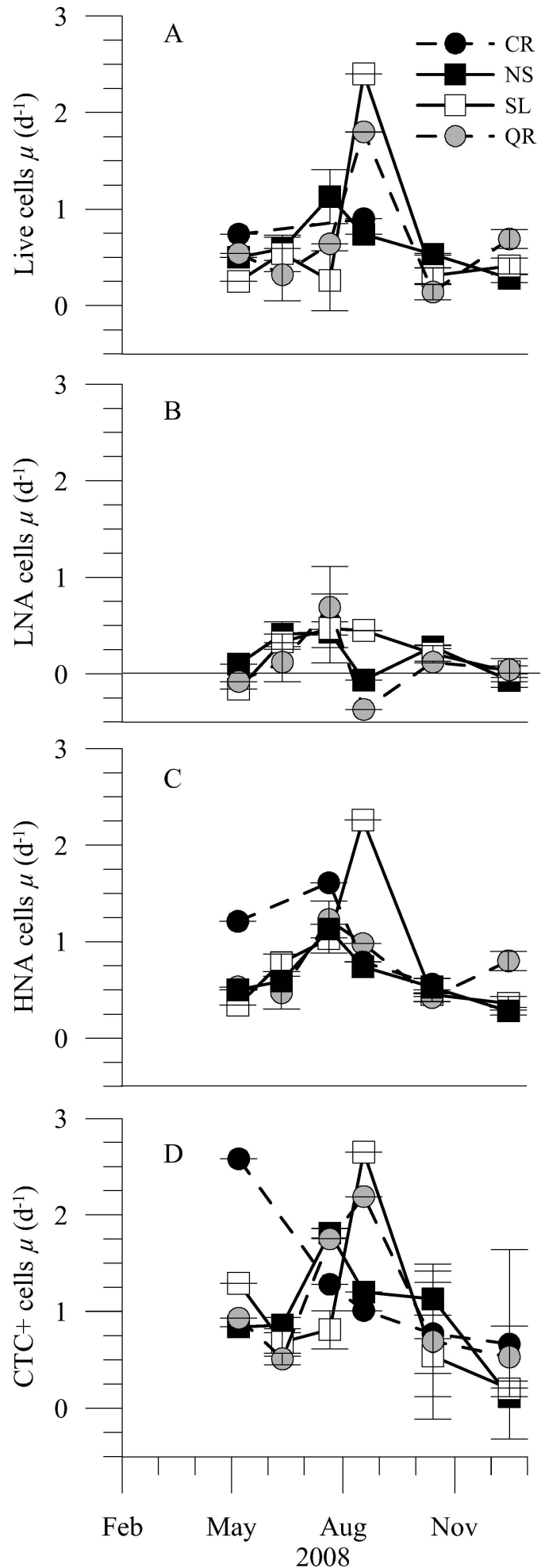

Fig. 1. Seasonal changes in the specific growth rates $( \pm \mathrm{SE})$ estimated in the dilution experiments of (A) live, (B) LNA, (C) HNA, and (D) CTC+ cells at the four sites sampled. The $\mu$ values were calculated as the slope of ln-transformed abundances during the exponential phase of growth (usually $<48$ h).CR, Childs River; NS, Nantucket Sound; SL, Sage Lot Pond; QR, Quashnet River. three groups had clearly different temperature dependences (Fig. 6). The contribution of 1-HNA decreased from as much as $80 \%$ at $7-8^{\circ} \mathrm{C}$ to $\sim 40 \%$ at $27^{\circ} \mathrm{C}$, with the opposite trend for $\mathrm{CTC}+\mathrm{HNA}$ cells, which increased from $<10 \%$ at low temperatures and contributed virtually the same as 1HNA at high temperatures. In spite of the sporadic lack of contribution on 1-LNA cells over the whole temperature range, values higher than $20 \%$ were not rare, and the highest contributions of this group (exceeding 30\%) were observed at intermediate temperatures.

\section{Discussion}

Heterotrophic bacterioplankton standing stocks are composed of cells with different physiological states and, as we assessed here, varying contributions to carbon fluxes. With the aim of understanding the dynamics and controls of live, LNA, HNA, and CTC+ bacteria in Waquoit Bay, we used dilution without prefiltration of the the inocula (Beardsley et al. 2003) to avoid disrupting cells and artificially increasing DOC availability (Gasol and Morán 1999; Fuchs et al. 2000). Most physiological groups increased in numbers during the first 6 to $26 \mathrm{~h}$. With few (usually $<15 \%$ ) dead cells as characterized by PI staining, the three subpopulations LNA, HNA, and CTC+ grew exponentially at different rates, together explaining the bulk bacterial metabolism at this site. The absence of sudden changes in abundance during the incubations and the consistent relationships found between the specific growth rates of the various physiological groups (Fig. 2) suggest that the potential migration of cells between the assigned flow cytometric groups was negligible. This assumption lies at the basis of an abundant body of literature comparing cell-specific activities, especially those of LNA and HNA cells (Zubkov et al. 2004; Longnecker et al. 2005; Jost et al. 2008).

Dynamics of single-cell physiological structure and controlling factors-In Waquoit Bay, the relative abundances of live, HNA, and CTC+ cells were in the ranges found in other coastal environments (Longnecker et al. 2005; Alonso-Sáez et al. 2006; Morán and Calvo-Díaz 2009). Absolute abundances of all groups closely followed changes in temperature (Table 2), as is typical for temperate (Steinberg et al. 2001; Alonso-Sáez et al. 2008) and estuarine waters, including nearby regions (Wright and Coffin 1983; Staroscik and Smith 2004), thus suggesting a major role of temperature in shaping bacterial standing stocks. The percentage of CTC + cells has been shown to increase with temperature and trophic state in Arctic freshwater lakes (Ellis-Evans et al. 2001), and Table 2 suggests that, besides temperature, bulk DOC concentration and primary production determined CTC + cell abundance. Like in Morán and Calvo-Díaz (2009), \% CTC+ was the index most correlated with total activity, and it was the only one that could be partly (25-42\%) predicted by changes in bottom-up factors (Table 2).

In order to better identify the mechanisms regulating the abundance of the physiological groups, we determined their specific growth rates. Assuming that only PI-negative (live) 
Table 3. Pearson correlation coefficients between the specific growth rates $(\mu)$ of total, live, LNA, HNA, and CTC+ bacteria and selected abiotic and biotic variables in Waquoit Bay during 2008; $n=22-24$. Significant correlations are indicated in bold with the level of significance: $* p<0.05, * * p<0.01, * * * p<0.001$. Units and abbreviations are as in Table 1 .

\begin{tabular}{|c|c|c|c|c|c|c|c|c|c|c|}
\hline & $\mu_{\text {total }}$ & $\mu_{\text {Live }}$ & $\mu_{\text {LNA }}$ & $\mu_{\mathrm{HNA}}$ & $\mu_{\text {CTC }+}$ & Temp & DOC & $\mathrm{PO}_{4}$ & DPP & PPP \\
\hline \multicolumn{11}{|l|}{$\mu_{\text {total }}$} \\
\hline$\mu_{\text {Live }}$ & $0.58 * *$ & & & & & & & & & \\
\hline$\mu_{\mathrm{LNA}}$ & $0.77 * * *$ & 0.01 & & & & & & & & \\
\hline$\mu_{\mathrm{HNA}}$ & $0.93 * * *$ & $0.81 * * *$ & $0.53 * *$ & & & & & & & \\
\hline$\mu_{\mathrm{CTC}+}$ & $0.59 * * *$ & $0.76 * * *$ & 0.12 & $0.77 * * *$ & & & & & & \\
\hline Temp & $0.53 *$ & $0.43 *$ & $0.42 *$ & $0.57 * *$ & $0.46^{* * *}$ & & & & & \\
\hline DOC & $0.51 *$ & 0.38 & 0.33 & $0.55 * *$ & 0.30 & $0.59 * *$ & & & & \\
\hline $\mathrm{PO}_{4}$ & $0.46^{*}$ & 0.34 & 0.42 & 0.41 & 0.36 & 0.38 & 0.27 & & & \\
\hline DPP & $0.58 * *$ & $0.63^{* *}$ & 0.31 & $0.66 * * *$ & $0.47 *$ & $0.73 * * *$ & $0.57 * *$ & $0.57 * *$ & & \\
\hline PPP & 0.40 & $0.55 * *$ & 0.18 & $0.50 *$ & 0.32 & $0.74 * *$ & $0.55 * *$ & 0.32 & $0.75 * * *$ & \\
\hline ТPP & $0.45 *$ & $0.60 * *$ & 0.20 & $0.55^{* *}$ & 0.36 & $0.75^{* *}$ & $0.58 * *$ & 0.36 & $0.81 * * *$ & $0.96 * * *$ \\
\hline
\end{tabular}
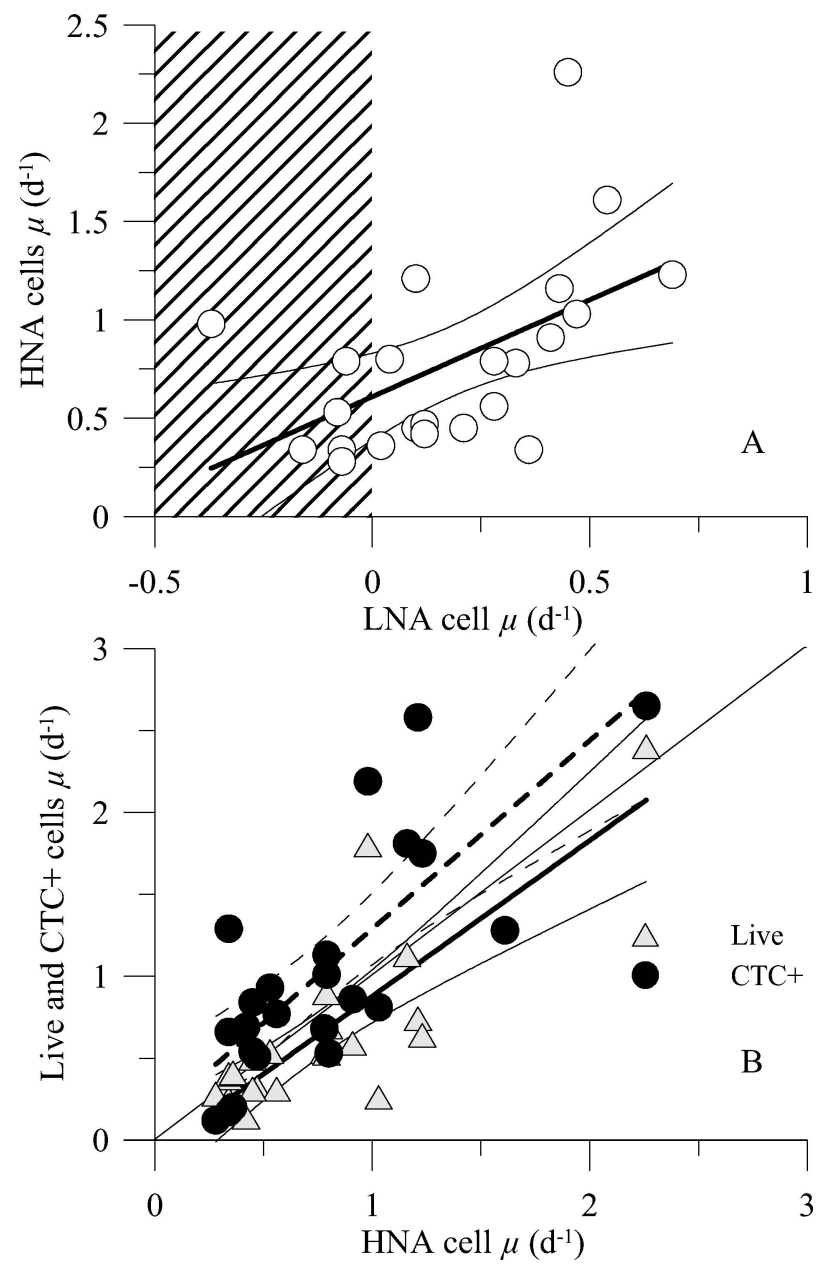

Fig. 2. Comparison between the specific growth rates of $(\mathrm{A})$ HNA vs. LNA bacteria $\left(y=0.61+0.98 x, r^{2}=0.28, p=0.01, n=\right.$ $23)$ and (B) between live $\left(y=-0.07+0.95 x, r^{2}=0.66, p<0.001\right.$, $n=22$, continuous line) and CTC + cells vs. HNA cells $(y=0.14+$ $1.15 x, r^{2}=0.60, p<0.001, n=23$, dashed line). Thin solid line is $1: 1$, and fitted OLS regressions are represented with $95 \%$ confidence intervals. cells can grow, the growing assemblage was composed of three distinct fractions with increasing $\mu$ values: LNA, HNA, and CTC+ (this being likely a subgroup of HNA cells). Bulk and live cell $\mu$ values were statistically indistinguishable (mean values of 0.51 and $0.64 \mathrm{~d}^{-1}$, respectively, paired $t$-test, $t=-1.43, \mathrm{df}=21, p=0.17$ ). LNA cells actually grew in $\sim 80 \%$ of our experiments, contrary to some observations (Gasol et al. 1999). Nonetheless, growth of LNA cells was on average $64 \%$ lower than HNA (Fig. 2A) and far from the values

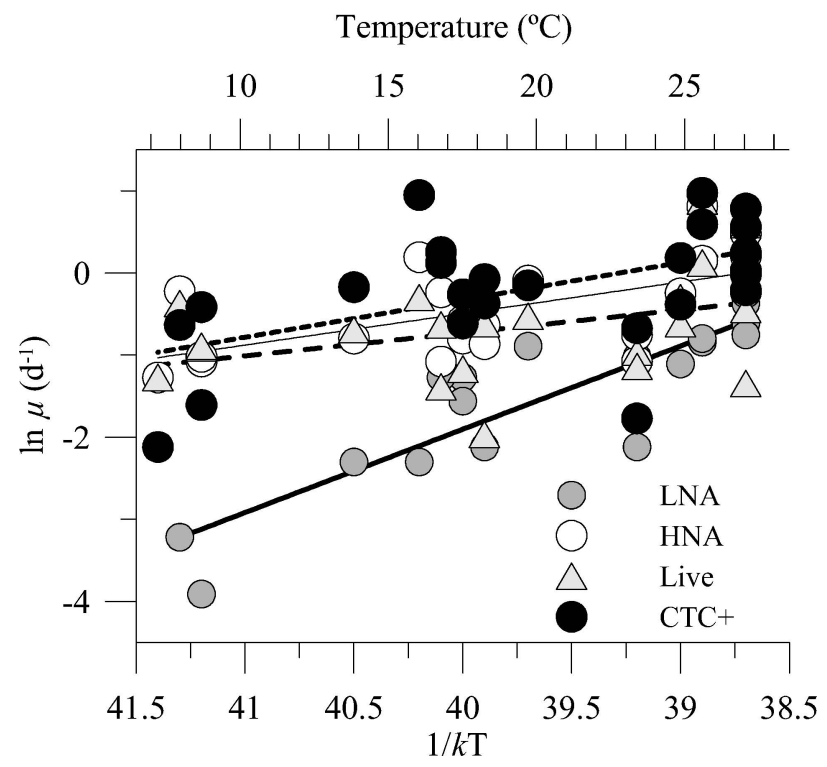

Fig. 3. Arrhenius plot with the relationships between pooled specific growth rates of the four physiological fractions and the temperature function $1 / k \mathrm{~T}$. Negative LNA cells specific growth rates were omitted in this analysis. Fitted lines are OLS linear regressions: Live, $\ln y=10.41-0.28 x, r^{2}=0.15, p=0.08, n=$ 23, dashed line; LNA, ln $y=38.04-1.00 x, r^{2}=0.77, p<0.001$, $n=17$, thick continuous line; HNA, $\ln y=14.72-0.38 x, r^{2}=$ $0.39, p=0.001, n=23$, thin continuous line; CTC + , $\ln y=17.66$ $-0.45 x, r^{2}=0.77, p=0.01, n=24$, dotted line. $k$, Boltzmann's constant $\left(8.6210^{-5} \mathrm{eV} \mathrm{K}^{-1}\right) ; \mathrm{T}$, absolute temperature in $\mathrm{K}$. 

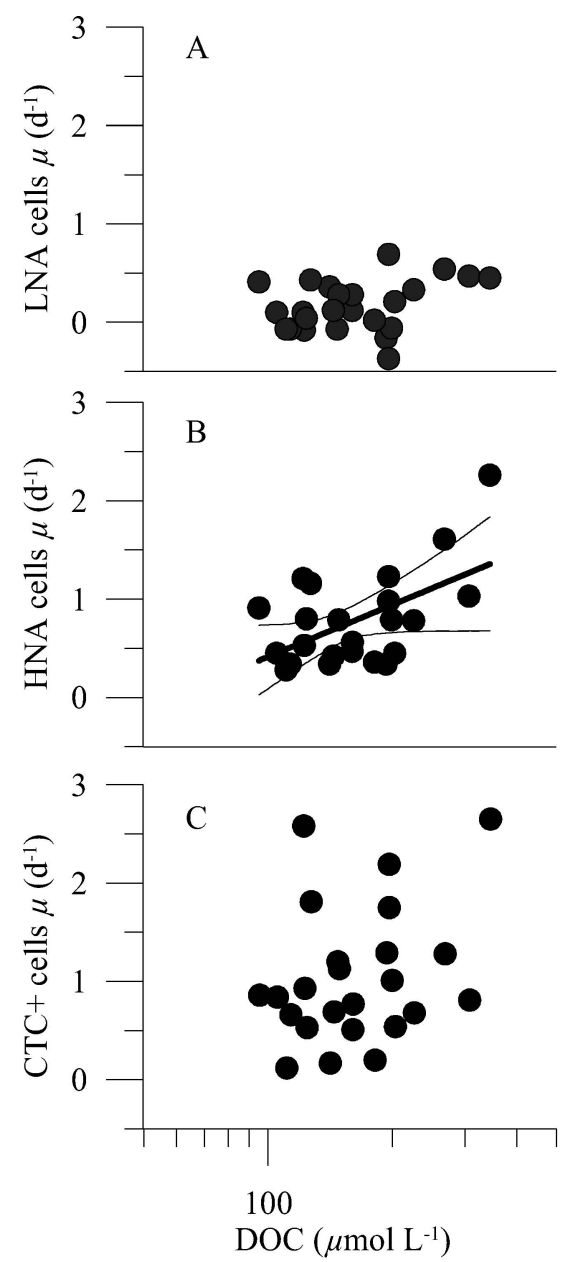
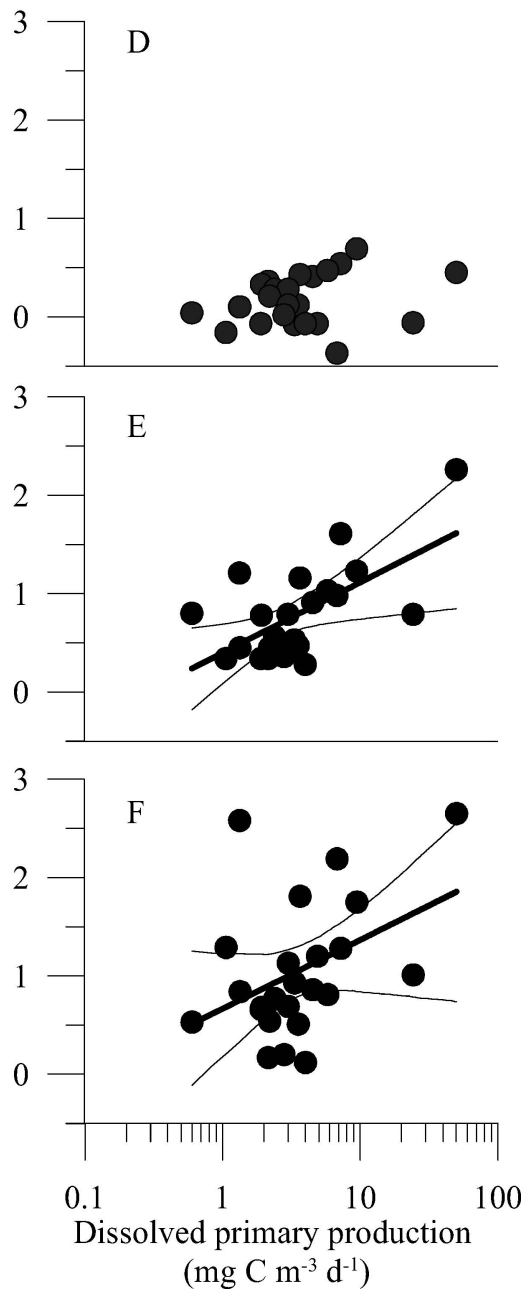

Fig. 4. Relationships between (A, B, C) DOC concentration and (D, E, F) the rates of dissolved primary production and the specific growth rates of LNA, HNA, and CTC+ cells for all data pooled. Fitted lines are OLS linear regressions with $95 \%$ confidence intervals indicating the significant correlations detailed in Table 3.

reported by Zubkov et al. (2001) and Mary et al. (2006) for the open Atlantic Ocean.

The fraction of cells in a given physiological group is a balance between growth and removal rates. Although all groups' $\mu$ values usually peaked in summer (Fig. 1), maxima in the relative abundance of HNA and CTC+ bacteria were generally found before or after that period (data not shown), possibly due to preferential grazing on the more active cells. A decrease in \% HNA values may be caused directly by protistan consumption (Gasol et al. 1999) and indirectly through trophic cascades (Zöllner et al. 2009) or viral activity (Bonilla-Findji et al. 2008). Similarly, removal of the reportedly more active (Del Giorgio et al. 1997; Morán and Calvo-Díaz 2009) and consequently more nutritious CTC+ cells likely precluded the dominance of this group in spite of their higher specific growth rates (Figs. 1, 2B). CTC+ $\mu$ values were the only values correlated with leucine incorporation rates $(r=0.50, p=$ $0.01, n=24)$, supporting the leading role of actively respiring cells in community metabolism in spite of their low numbers (Smith 1998; Choi et al. 1999; Sherr et al.
1999). Total number and relative abundance of CTC+ cells have also been shown recently to be the best predictor of bulk activity and growth rates year-round in temperate Atlantic shelf waters (Morán and Calvo-Díaz 2009).

In addition to temperature and substrate availability, salinity was a key variable associated with the fraction of live cells (Table 2), as previously reported (Del Giorgio and Bouvier 2002). Salinity was also inversely correlated with the percentage of HNA cells, as found by Joux et al. (2005) and Morán et al. (2002b), but our results suggest that the LNA subgroup in Waquoit Bay differs from that found in other coastal sites, where no growth was observed (Gasol et al. 1999; Vaqué et al. 2001). However, comparatively lower but significant positive growth of SAR11 bacteria, appearing only within the LNA subgroup and dominating it (Mary et al. 2006; M. V. Zubkov and B. Fuchs pers. comm.), has been recently reported in the Ría de Vigo (Teira et al. 2009). LNA cells have also been shown to actively grow in other marine (Jochem et al. 2004; Longnecker et al. 2005; Scharek and Latasa 2007) and freshwater (Wang et al. 2009) ecosystems. Consequently, 
Table 4. Results of stepwise multiple regression analysis of the specific growth rates of total, live, LNA, HNA, and CTC+ cells as dependent variables and the independent variables salinity (Salt), phosphate concentration $\left(\mathrm{PO}_{4}\right)$, DOC concentration, dissolved primary production $(\mathrm{DPP})$, and bacterial biovolume $(\mathrm{BBv})$. df, degrees of freedom. Significance of beta values: $* p<0.05$, $* * p<0.01$, $* * * p<0.001$.

\begin{tabular}{|c|c|c|c|c|c|c|c|c|c|c|}
\hline \multirow{2}{*}{$\begin{array}{l}\text { Specific } \\
\text { growth rate }\end{array}$} & \multirow[b]{2}{*}{ Intercept } & \multicolumn{5}{|c|}{ Coefficients } & \multicolumn{4}{|c|}{ Full regression statistics } \\
\hline & & Salt & $\mathrm{PO}_{4}$ & DOC & DPP & $\mathrm{BBv}$ & df & $F$ & $p$ & $r^{2}$ \\
\hline Total & -1.72 & - & 0.31 & 0.82 & 0.20 & - & 3,18 & 4.56 & 0.015 & 0.43 \\
\hline Live & 6.81 & - & - & & $0.64 * *$ & $5.78 *$ & 2,19 & 10.21 & $<0.010$ & 0.52 \\
\hline LNA & -6.89 & - & 0.27 & $0.83^{*}$ & - & $-4.08 *$ & 3,19 & 5.02 & 0.010 & 0.44 \\
\hline HNA & -2.21 & - & - & 0.96 & $0.51 *$ & - & 2,19 & 9.69 & 0.001 & 0.50 \\
\hline CTC+ & 12.69 & 0.04 & - & - & $0.58 *$ & 10.86 & 3,19 & 3.96 & 0.024 & 0.38 \\
\hline
\end{tabular}

we should no longer regard LNA bacteria as inactive cells, even in coastal or eutrophic regions, without unequivocally demonstrating that their growth was negligible.

In Waquoit Bay, all single-cell groups showed positive and high correlations between abundance and temperature over their full observed range (Table 2). In nearby Narragansett Bay, temperature was significantly correlated with total bacterial abundance but not with specific growth rates (Staroscik and Smith 2004). Here, the respective $\mu$ values and temperature were also correlated but with lower coefficients, and for all groups except LNA cells, the highest correlations were obtained with other variables (Table 3). Moreover, due to the strong covariation between temperature and substrate availability in Waquoit Bay, the multiple regression approach to separate these factors argues against a preponderant role of temperature (Table 4). Our analysis shows that the supply of substrates (phytoplankton-derived and bulk DOC, and also $\mathrm{PO}_{4}$ for LNA cells), and only secondarily temperature, drove the response of physiological single-cell fractions in Waquoit Bay. Contrary to other studies (Hoch and Kirchman 1993;

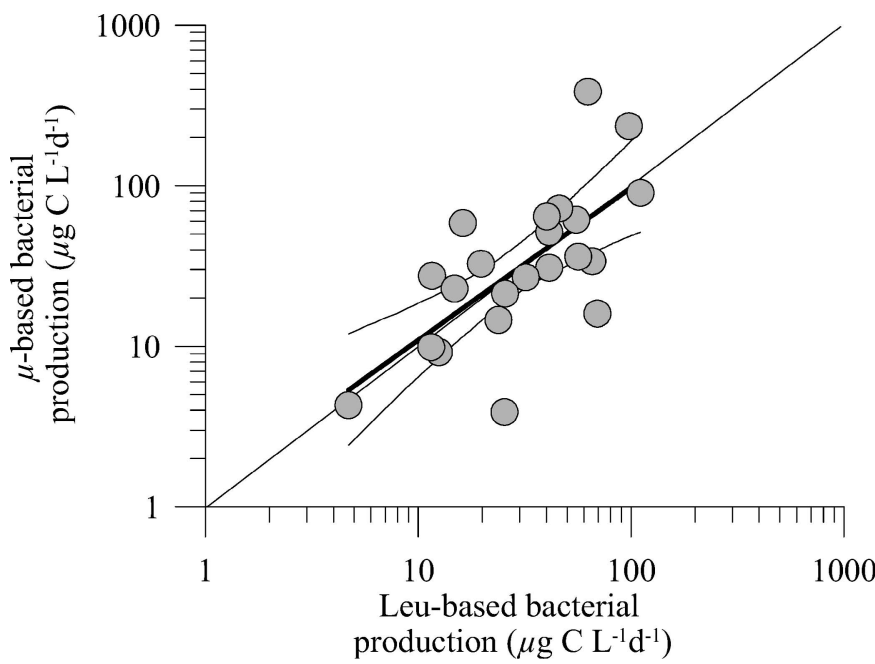

Fig. 5. Relationship between bacterial production estimated from leucine incorporation rates and empirically determined Leu to $\mathrm{C}$ conversion factors and bacterial production estimates using in situ biomass and bulk specific growth rates (i.e., the sum of LNA and HNA cells). Fitted thick line is OLS linear regression: $\log y=0.09+0.95 \log x, r^{2}=0.46, p<0.001, n=22$, and thin lines represent $95 \%$ confidence intervals.
Shiah and Ducklow 1994a,b), there was no plateau value in the apparent temperature dependence in bacterial growth or production (Figs. 3, 6B).
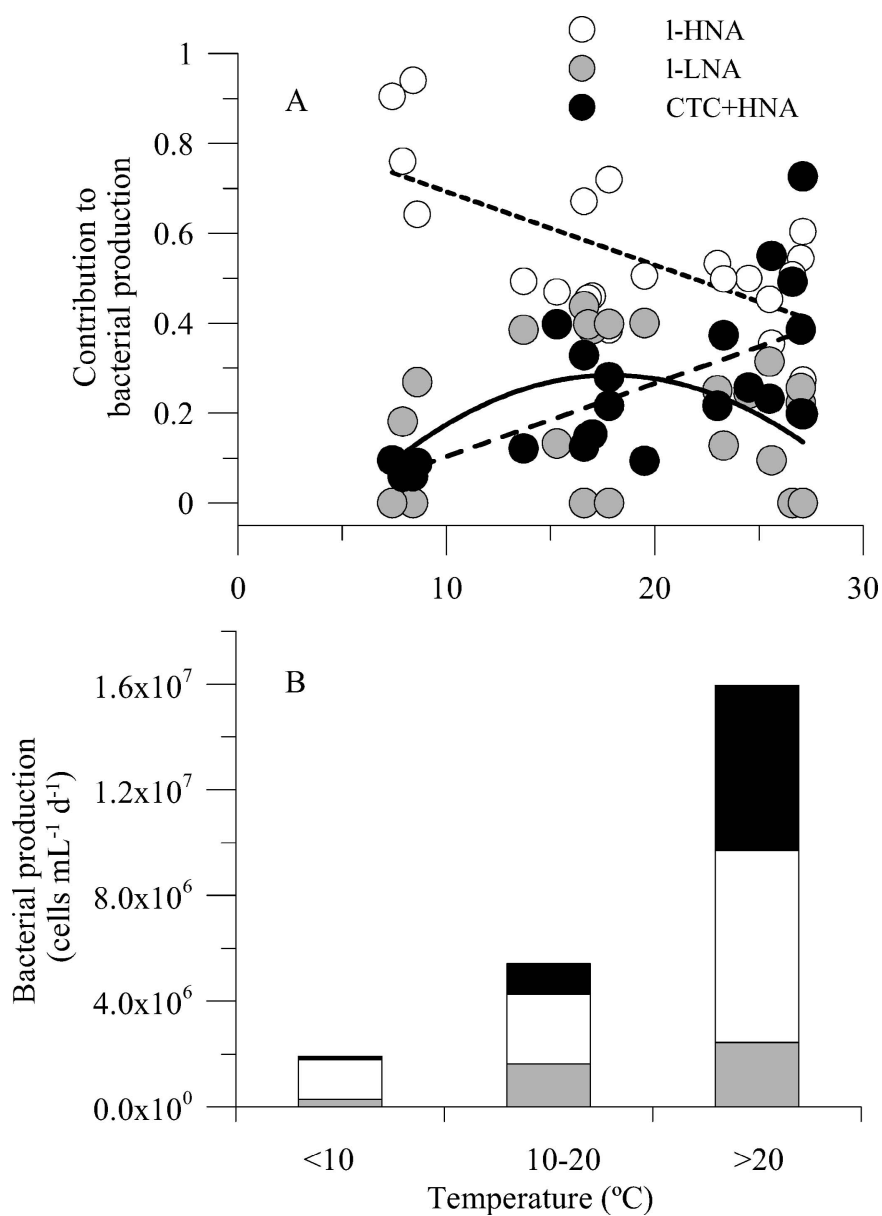

Fig. 6. (A) Relationship between the contribution of live LNA, live HNA, and CTC+HNA cells to total bacterial carbon production and temperature for all data pooled $(n=23)$. Fitted lines: $y=0.86-0.02\left(\%\right.$ HNA),$r^{2}=0.45 p<0.001$, dotted line; $y$ $=-0.06+0.02(\% \mathrm{CTC}+), r^{2}=0.42, p<0.001$, dashed line. A quadratic fitting was applied to LNA data for guidance. (B) Mean contribution of live LNA, live HNA, and CTC+HNA cells to total bacterial production (cells $\mathrm{mL}^{-1} \mathrm{~d}^{-1}$ ) in Waquoit Bay estimated from initial abundances and single-cell specific growth rates at three different temperature ranges: $<10^{\circ} \mathrm{C}, 10-20^{\circ} \mathrm{C}$, and $>20^{\circ} \mathrm{C}$. Details of the calculations are given in the text. 
Additional support for the greater role of substrate availability relative to temperature in controlling bacterial growth is the apparent response of physiological groups to temperature (Fig. 3). With no substrate limitation, warming increases enzymatic activity and hence cell division, as described by the metabolic theory of ecology (MTE; Brown et al. 2004), with activation energies $\left(E_{\mathrm{a}}\right)$ for heterotrophs gathering around $0.65 \mathrm{eV}$ (Gillooly et al. 2001; LópezUrrutia and Morán 2007). However, the energy of activation was $0.3-0.4 \mathrm{eV}$, equivalent to $Q_{10}$ of $1.5-1.9$, for all groups (Fig. 3) except LNA bacteria, which yielded a significantly higher value of $1.0 \mathrm{eV}$. Freshwater LNA cells also gave a relatively high $E_{\mathrm{a}}(0.55 \mathrm{eV}$; Wang et al. 2009). It is tempting to suggest that lower $E_{\mathrm{a}}$ values are related to a greater dependence of the most active (HNA and CTC+) cells on photosynthesis, which has an activation energy of $0.32 \mathrm{eV}$. Although according to the MTE, $Q_{10}$ values of bacteria should be higher than those of phytoplankton (López-Urrutia et al. 2006), in situ measurements show high variation (Kirchman et al. 1995; Pedrós-Alió et al. 2002), with lower values likely related to substrate limitation (López-Urrutia and Morán 2007). Altogether, these results suggest that the dependence of LNA cells on autotrophic processes is substantailly different from that of HNA and CTC+ cells.

According to Church (2008), DOM is the most frequent limiting factor for bacterial growth. The dependence of bacteria on the amount of dissolved substrates has been demonstrated for many pelagic ecosystems (Carlson and Ducklow 1996; Kähler et al. 1997; Morán et al. 2002a), including estuarine waters (Findlay et al. 1991; Hoch and Kirchman 1993). In a recent study by Yokokawa and Nagata (2005), different phylogenetic groups had different relationships with $\mathrm{Chl} a$, suggesting that the dependence on phytoplankton substrates was not consistent among bacterial groups. Frequently, this assessment is made with proxies such as Chl $a$ (Sherr et al. 2006) or particulate primary production (Kirchman et al. 2009). This is to our knowledge the first report in which the effect of total vs. phytoplankton-produced DOC was simultaneously assessed for various physiological fractions, with clearly different responses (Tables 3,4). In particular, $\mu$ values of HNA bacteria but not of LNA bacteria showed consistently positive responses to enhanced organic substrate availability (Fig. 4), confirming previous suggestions (Morán et al. 2010). Live and CTC+ cell $\mu$ values also seemed to depend more on DPP than on bulk organic or inorganic nutrients (Table 3; Fig. 4). The hypothesis that HNA cells are mostly dependent on phytoplankton-produced DOC ( $\mathrm{Li}$ et al. 1995; Morán et al. 2007; Scharek and Latasa 2007) had received indirect support previously (Corzo et al. 2005; Belzile et al. 2008; Morán et al. 2010).

Conversely, these results also indicate a lower degree of trophic dependence of LNA bacteria on DPP as recently suggested for the eastern North Atlantic (Morán et al. 2010). Mean bacterial biovolume $\left(0.048-0.065 \mu \mathrm{m}^{3}\right)$ had positive coefficients in the multiple regressions of live and CTC+ cell specific growth rates, suggesting that larger cells are the most active ones in terms of respiratory activity (Gasol et al. 1995; Søndergaard and Danielsen 2001; Morán and Calvo-Díaz
2009). Biovolume was also included in the LNA $\mu$ stepwise regression results, but with a negative coefficient (Table 4), thus arguing for a fundamentally different regulation of LNA and HNA bacteria or at least compelling differences between activity and cell size.

Contribution of physiological groups to bacterial production-Bulk specific growth rates were uniformly below $1.5 \mathrm{~d}^{-1}$, in accordance with other reports from estuarine environments (Revilla et al. 2000; Yokokawa et al. 2004), but higher than the average $0.1 \mathrm{~d}^{-1}$ characteristic of most open-ocean waters (Kirchman et al. 2009). Compared with oligotrophic sites, higher bacterial specific growth rates are expected in mesotrophic to eutrophic surface estuarine waters such as Waquoit Bay. However, between 18\% and $58 \%$ bacteria were LNA cells growing at relatively low rates $\left(<0.5 \mathrm{~d}^{-1}\right.$; Fig. 2A). By this logic, low water-column integrated BP : BB ratios (as in Kirchman et al. 2009) would thus be indicative of the presence of large numbers of cells with low activity. It is not always the case that estimated (BP : BB ratios) and measured (from dilution experiments) $\mu$ values are statistically not different as we found in Waquoit Bay. Rather, BP:BB estimates are frequently much lower than measurements carried out in predator-free incubations (Ducklow 2000; L. Franco-Vidal and X. A. G. Morán unpubl.). Here, the use of empirically determined LCF rather than a fixed theoretical value $(3.1 \mathrm{~kg} \mathrm{C}$ mol $\mathrm{Leu}^{-1}$ ) improved the agreement between the two methods of estimating total carbon flux through bacterioplankton, raising the percentage of variance explained from 35\% (data not shown) to $46 \%$ (Fig. 5).

At short timescales, CTC+ cells can increase dramatically in response to algal blooms without no change in temperature (Yager et al. 2001). Temperature was not as important as dissolved organic matter availability in determining the specific growth rates of LNA, HNA, and $\mathrm{CTC}+$ cells in Waquoit Bay. However, it was clearly associated with the percent contribution to total BP of the three mutally exclusive physiological groups 1-LNA, 1HNA, and CTC+HNA (Fig. 6A). While the contribution of non-actively respiring HNA cells (1-HNA) steadily decreased in warm waters, the combination of high substrate availability (Table 1) and higher enzymatic rates made CTC+HNA cells contribute up to $>50 \%$ ot total carbon assimilation at temperatures $>25^{\circ} \mathrm{C}$. This result is the first direct demonstration of the key contribution of $\mathrm{CTC}+$ cells to bacterial carbon production in pelagic ecoystems at high temperatures, confirming the mechanism underlying indirect associations between CTC+ cell abundance or \% CTC+ cells and bulk bacterial activity (Lovejoy et al. 1996; Choi et al. 1999; Sherr et al. 1999). The contribution of 1-HNA bacteria with lower specific growth rates (cf. Fig. 1C,D) was clearly dominant at temperatures below $20^{\circ} \mathrm{C}$ (Fig. 6B), while 1-LNA cells also contributed up to $40 \%$ to $\mathrm{BP}$ at specific sites and intermediate temperatures around $15^{\circ} \mathrm{C}$ (Fig. 6A). This was somewhat surprising if this group is made up solely of inactive or even dead cells (Gasol et al. 1999). Accumulating evidence during the last decade (Zubkov et al. 2001; Jochem et al. 2004; Scharek and Latasa 2007) indicates that LNA 
bacteria can sometimes be nearly as active as HNA cells (Longnecker et al. 2005). LNA were a minor group here, especially at low and high temperatures, but this was not always the case. However, considering that HNA bacteria include CTC+ cells, they contributed $\sim 60-100 \%$ of bacterial production.

It is currently possible to easily discriminate by flow cytometry between bacterial cells with differing metabolic and physiological states, but this diversity is seldom considered, especially in models, where the black-box approach is still widespread. In the estuarine system of Waquoit Bay, a heterogeneous bacterial community in terms of physiological states persisted year-round. The majority of cells were viable, and most of the bacterial assemblage growth was due to the division of HNA cells. Unlike LNA cells, HNA cells were likely strongly dependent on phytoplankton-derived DOC. The eutrophic nature of the site favored a good agreement between bacterial production estimates using experimental specific growth rates and leucine incorporation rates. Among the HNA group, the contribution of the highly active subgroup of CTC + bacteria to total biomass production increased with increasing temperature, reaching $\sim 40 \%$ at values higher than $20^{\circ} \mathrm{C}$.

\section{Acknowledgments}

We thank all people at the Ecosystems Center (Marine Biological Laboratory), especially S. Aebischer, Y. Luo, K. Meyers, S. Fox, Y. Olsen, and R. Monteiro for their support during sampling and experimental work, and L. Alonso-Sáez and two anonymous referees for their enlightening comments on earlier versions of the manuscript. This study was supported by the Spanish Ministry of Science and Innovation (MICINN) sabbatical stay program (to X.A.G.M.), National Science Foundation Office of Polar Programs grant 0823101 to H.W.D., and by the Marine Biological Laboratory.

\section{References}

Alonso-Sáez, L., J. M. Gasol, T. Lefort, J. Hofer, and R. Sommaruga. 2006. Effect of natural sunlight on bacterial activity and differential sensitivity of natural bacterioplankton groups in northwestern Mediterranean coastal waters. Appl. Environ. Microbiol. 72: 5806-5813, doi:10.1128/ AEM.00597-06

— AND OTHERS. 2008. Factors controlling the year-round variability in carbon flux through bacteria in a coastal marine system. Ecosystems 11: 397-409, doi:10.1007/s10021-008-9129-0

Beardsley, C., J. Pernthaler, W. Wosniok, and R. Amann. 2003. Are readily culturable bacteria in coastal North Sea waters suppresed by selective grazing mortality? Appl. Environ. Microbiol. 69: 2624-2630, doi:10.1128/AEM. 69.5.2624-2630.2003

Belzile, C., S. Brugel, C. Nozais, Y. Gratton, and S. Demers. 2008. Variations of the abundance and nucleic acid content of heterotrophic bacteria in Beaufort Shelf waters during winter and spring. J. Mar. Sys. 74: 946-956, doi:10.1016/j.jmarsys. 2007.12.010

Bonilla-Findji, O., A. Malits, D. Lefèvre, E. RochelleNewall, R. Lemée, M. G. Weinbauer, and J.-P. Gattuso. 2008. Viral effects on bacterial respiration, production and growth efficiency: Consistent trends in the Southern Ocean and the Mediterranean Sea. Deep-Sea Res. II 55: 790-800, doi:10.1016/j.dsr2.2007.12.004
Bouvier, T., P. A. Del Giorgio, and J. M. Gasol. 2007. A comparative study of the cytometric characteristics of high and low nucleic-acid bacterioplankton cells from different aquatic ecosystems. Environ. Microbiol. 9: 2050-2066, doi:10.1111/j.1462-2920.2007.01321.x

Brown, J. H., J. F. Gillooly, A. P. Allen, V. M. SAvage, and G. B. West. 2004. Toward a metabolic theory of ecology. Ecology 85: 1771-1789, doi:10.1890/03-9000

Calvo-Díaz, A., and X. A. G. Morán. 2009. Empirical leucine-tocarbon conversion factors for estimating heterotrophic bacterial production: Seasonality and predictability in a temperate coastal ecosystem. Appl. Environ. Microbiol. 75: 3216-3221, doi:10.1128/ AEM.01570-08

Carlson, C. A., AND H. W. Ducklow. 1996. Growth of bacterioplankton and consumption of dissolved organic carbon in the Sargasso Sea. Aquat. Microb. Ecol. 10: 69-85, doi:10.3354/ame010069

Choi, J. W., B. F. Sherr, And E. B. Sherr. 1999. Dead or alive? A large fraction of ETS-inactive marine bacterioplankton cells, as assessed by reduction of CTC, can become ETS-active with incubation and substrate addition. Aquat. Microb. Ecol. 18: 105-115, doi:10.3354/ame018105

Church, M. J. 2008. Resource control of bacterial dynamics in the sea, p. 335-382. In D. L. Kirchman [ed.], Microbial ecology of the oceans, 2nd ed. Wiley-Liss.

Comte, J., And P. A. Del Giorgio. 2009. Links between resources, $\mathrm{C}$ metabolism and the major components of bacterioplankton community structure across a range of freshwater ecosystems. Environ. Microbiol. 11: 1704-1716, doi:10.1111/j.1462-2920. 2009.01897.x

Corzo, A., S. Rodríguez-Gálvez, L. Lubian, C. Sobrino, P. SANGRÁ, AND A. MARTínez. 2005. Antarctic marine bacterioplankton subpopulations discriminated by their apparent content of nucleic acids differ in their response to ecological factors. Polar Biol. 29: 27-39, doi:10.1007/s00300-005-0032-2

Del Giorgio, P. A., And T. C. Bouvier. 2002. Linking the physiologic and phylogenetic successions in free-living bacterial communities along an estuarine salinity gradient. Limnol. Oceanogr. 47: 471-486, doi:10.4319/lo.2002.47.2.0471

- AND J. M. GASOL. 2008. Physiological structure and single-cell activity in marine bacterioplankton, p. 243-298. In D. L. Kirchman [ed.], Microbial ecology of the oceans, 2nd ed. Wiley-Liss.

\section{, - D. Vaqué, P. Mura, S. Agustí, and C. M.} DuARTE. 1996. Bacterioplankton community structure: Protists control net production and the proportion of active bacteria in a coastal marine community. Limnol. Oceanogr. 41: 1169-1179, doi:10.4319/1o.1996.41.6.1169

, Y. T. Prairie, AND D. F. Bird. 1997. Coupling between rates of bacterial production and the abundance of metabolically active bacteria in lakes, enumerated using CTC reduction and flow cytometry. Microb. Ecol. 34: 144-154, doi: $10.1007 / \mathrm{s} 002489900044$

Ducklow, H. 2000. Bacterial production and biomass in the oceans, p. 85-120. In D. L. Kirchman [ed.], Microbial ecology of the oceans. Wiley-Liss.

, C. Carlson, M. Church, D. Kirchman, D. Smith, and G. STEWARD. 2001. The seasonal development of the bacterioplankton bloom in the Ross Sea, Antarctica, 1994-1997. Deep-Sea Res. II 48: 4199-4221, doi:10.1016/S0967-0645(01)00086-8

- , AND W. SMith. 1999. Bacterial growth in experimental plankton assemblages and seawater cultures from the Phaeocystis antarctica bloom in the Ross Sea, Antarctica. Aquat. Microb. Ecol. 19: 215-227, doi:10.3354/ame019215

- X. A. G. Morán, And A. E. Murray. 2010. Bacteria in the greenhouse: Marine microbes and climate change, p. 1-31. In R. Mitchell and J. D. Gu [eds.], Environmental microbiology, 2nd ed. Wiley-Blackwell. 
Ellis-Evans, J. C., V. Galchenko, J. Laybourn-Parry, A. P. Mylnikov, And W. Petz. 2001. Environmental characteristics and microbial plankton activity of freshwater environments at Kongsfjorden, Spitsbergen (Svalbard). Archiv Hydrobiol. 152: 609-632.

Feuerpfeil, P., AND others. 2004. Carbon budget and pelagic community compositions at two coastal areas that differ in their degree of eutrophication, in the Southern Baltic Sea. Estuar. Coast. Shelf Sci. 61: 89-100, doi:10.1016/j.ecss.2004.04.006

Findlay, S., M. L. Pace, D. Lints, J. J. Cole, N. F. Caraco, and B. Peierls. 1991. Weak coupling of bacterial and algal production in a heterotrophic ecosystem: The Hudson River estuary. Limnol. Oceanogr. 36: 268-278, doi:10.4319/lo. 1991.36.2.0268

Fuchs, B. M., M. V. Zubkov, K. Sahm, P. H. Burkill, and R. Amann. 2000. Changes in community composition during dilution cultures of marine bacterioplankton as assessed by flow cytometric and molecular biological techniques. Environ. Microbiol. 2: 191-201, doi:10.1046/j.1462-2920.2000.00092.x

Gasol, J. M., And J. Arístegui. 2007. Cytometric evidence reconciling the toxicity and usefulness of CTC as a marker of bacterial activity. Aquat. Microb. Ecol. 46: 71-83, doi:10.3354/ame046071

- P. A. Del Giorgio, R. Massana, and C. M. Duarte. 1995. Active versus inactive bacteria: Size-dependence in coastal marine plankton community. Mar. Ecol. Prog. Ser. 128: $91-97$, doi:10.3354/meps 128091

—, AND X. A. G. MoRÁn. 1999. Effects of filtration on bacterial activity and picoplankton community structure as assessed by flow cytometry. Aquat. Microb. Ecol. 16: 251-264, doi:10.3354/ame016251

— U. L. Zweifel, F. Peters, J. A. Fuhrman, and Å. HAGström. 1999. Significance of size and nucleic acid content heterogeneity as measured by flow cytometry in natural planktonic bacteria. Appl. Environ. Microbiol. 65: 4475-4483.

Gillooly, J. F., J. H. Brown, G. B. West, V. M. Savage, and E. L. Charnov. 2001. Effects of size and temperature on metabolic rate. Science 293: 2248-2251, doi:10.1126/science. 1061967

Grégori, G., S. Citterio, A. Ghiani, M. Labra, S. Sgorbati, S. Brown, AND M. Denis. 2001. Resolution of viable and membrane-compromised bacteria in freshwater and marine waters based on analytical flow cytometry and nucleic acid double staining. Appl. Environ. Microbiol. 67: 4662-4670, doi:10.1128/AEM.67.10.4662-4670.2001

Hoch, M. P., And D. L. Kirchman. 1993. Seasonal and interannual variability in bacterial production and biomass in a temperate estuary. Mar. Ecol. Prog. Ser. 98: 283-295, doi: $10.3354 /$ meps098283

Jochem, F. J., P. J. Lavrentyev, And M. R. First. 2004. Growth and grazing rates of bacteria groups with different apparent DNA content in the Gulf of Mexico. Mar. Biol. 145: 1213-1225, doi:10.1007/s00227-004-1406-7

Jost, G., M. V. Zubkov, E. Yakushev, M. Labrenz, and K. JüRGENS. 2008. High abundance and dark $\mathrm{CO}_{2}$ fixation of chemolithoautotrophic prokaryotes in anoxic waters of the Baltic Sea. Limnol. Oceanogr. 53: 14-22.

Joux, F., P. Servais, J. J. Naudin, P. Lebaron, L. Oriol, and C. Courties. 2005. Distribution of picophytoplankton and bacterioplankton along a river plume gradient in the Mediterranean Sea. Vie Milieu-Life Environ. 55: 197-208.

Kähler, P., P. K. Buørnsen, K. Lochte, and A. Antia. 1997. Dissolved organic matter and its utilization by bacteria during spring in the Southern Ocean. Deep-Sea Res. II 44: 341-353, doi:10.1016/S0967-0645(96)00071-9
Kirchman, D. L. 2002. Calculating microbial growth rates from data on production and standing stocks. Mar. Ecol. Prog. Ser. 233: 303-306, doi: $10.3354 /$ meps 233303

—_ E. K'nees, And R. Hodson. 1985. Leucine incorporation and its potential as a measure of protein synthesis by bacteria in natural aquatic systems. Appl. Environ. Microbiol. 49: 599-607.

, X. A. G. Morán, And H. Ducklow. 2009. Microbial growth in the polar oceans - role of temperature and potential impact of climate change. Nature Rev. Microbiol. 7: 451-459.

- J. H. Rich, AND R. T. BARber. 1995. Biomass and biomass production of heterotrophic bacteria along $140^{\circ} \mathrm{W}$ in the equatorial Pacific: Effect of temperature on the microbial loop. Deep-Sea Res. II 42: 603-619, doi:10.1016/0967-0645 (95)00021-H

Lamy, D., L. F. Artigas, C. Jauzein, F. Lizon, and V. Cornille. 2006. Coastal bacterial viability and production in the eastern English Channel: A case study during a Phaeocystis globosa bloom. J. Sea Res. 56: 227-238, doi:10.1016/j.seares.2006.04.003

Li, W. K. W., J. F. Jellett, and P. M. Dickie. 1995. DNA distributions in planktonic bacteria stained with TOTO or TO-PRO. Limnol. Oceanogr. 40: 1485-1495, doi:10.4319/lo.1995.40.8.1485

Longnecker, K., B. F. Sherr, And E. B. Sherr. 2005. Activity and phylogenetic diversity of bacterial cells with high and low nucleic acid content and electron transport system activity in an upwelling ecosystem. Appl. Environ. Microbiol. 71: 7737-7749, doi:10.1128/AEM.71.12.7737-7749.2005

López-Urrutia, Á., and X. A. G. Morán. 2007. Resource limitation of bacterial production distorts the temperature dependence of oceanic carbon cycling. Ecology 88: 817-822, doi:10.1890/06-1641

, E. San Martin, R. P. Harris, and X. Irigoien. 2006. Scaling the metabolic balance of the oceans. Proc. Nat. Acad. Sci. USA 103: 8739-8744, doi:10.1073/pnas.0601137103

Lovejoy, C., L. Legendre, B. Klein, J. E. Tremblay, R. G. Ingram, AND J. C. Therriault. 1996. Bacterial activity during early winter mixing (Gulf of St. Lawrence, Canada). Aquat. Microb. Ecol. 10: 1-13, doi:10.3354/ame010001

Mary, I., J. L. Heywood, B. M. Fuchs, R. Amann, G. A. Tarran, P. H. Burkill, AND M. V. ZubKov. 2006. SAR11 dominance among metabolically active low nucleic acid bacterioplankton in surface waters along an Atlantic meridional transect. Aquat. Microb. Ecol. 45: 107-113, doi:10.3354/ame045107

Morán, X. A. G., A. Bode, L. Á. SuÁrez, and E. Nogueira. 2007. Assessing the relevance of nucleic acid content as an indicator of marine bacterial activity. Aquat. Microb. Ecol. 46: 141-152, doi:10.3354/ame046141

- And A. Calvo-Díaz. 2009. Single-cell vs. bulk activity properties of coastal bacterioplankton over an annual cycle in a temperate ecosystem. FEMS Microbiol. Ecol. 67: 43-56, doi:10.1111/j.1574-6941.2008.00601.x

- — phytoplankton mediated bottom-up control of bacterioplankton change with temperature in NE Atlantic shelf waters. Aquat. Microb. Ecol. 58: 229-239, doi:10.3354/ame01374

, M. Estrada, J. M. Gasol, and C. Pedrós-Alió. $2002 a$. Dissolved primary production and the strength of phytoplankton bacterioplankton coupling in contrasting marine regions. Microb. Ecol. 44: 217-223, doi:10.1007/s00248-002-1026-Z

, J. M. Gasol, C. Pedrós-Alió, and M. Estrada. $2002 b$. Partitioning of phytoplanktonic organic carbon production and bacterial production along a coastal-offshore gradient in the NE Atlantic during different hydrographic regimes. Aquat. Microb. Ecol. 29: 239-252, doi:10.3354/ame029239 
Pedrós-Alió, C., D. Vaqué, N. Guixa-Boixereu, and J. M. GaSOL. 2002. Prokaryotic plankton biomass and heterotrophic production in western Antarctic waters during the 1995 1996 Austral summer. Deep-Sea Res. II 49: 805-825, doi:10.1016/S0967-0645(01)00125-4

Revilla, M., A. Iriarte, I. Madariaga, and E. Orive. 2000. Bacterial and phytoplankton dynamics along a trophic gradient in a shallow temperate estuary. Estuar. Coast. Shelf Sci. 50: 297-313, doi:10.1006/ecss.1999.0576

Rodriguez, G. G., D. Phipps, K. Ishiguro, and H. F. Ridgway. 1992. Use of a fluorescent redox probe for direct visualization of actively respiring bacteria. Appl. Environ. Microbiol. 58: $1801-1808$

SchareK, R., And M. Latasa. 2007. Growth, grazing and carbon flux of high and low nucleic acid bacteria differ in surface and deep chlorophyll maximum layers in the NW Mediterranean Sea. Aquat. Microb. Ecol. 46: 153-161, doi:10.3354/ame046153

Schumann, R., U. Schiewer, U. Karsten, and T. Rieling. 2003. Viability of bacteria from different aquatic habitats. II. Cellular fluorescent markers for membrane integrity and metabolic activity. Aquat. Microb. Ecol. 32: 137-150, doi:10.3354/ame032137

Sherr, B. F., P. Del Giorgio, and E. B. Sherr. 1999. Estimating abundance and single-cell characteristics of respiring bacteria via the redox dye CTC. Aquat. Microb. Ecol. 18: 117-131, doi:10.3354/ame018117

Sherr, E. B., B. F. Sherr, and K. Longnecker. 2006. Distribution of bacterial abundance and cell specific nucleic acid content in the northeast Pacific Ocean. Deep-Sea Res. I 53: 713-725, doi:10.1016/j.dsr.2006.02.001

Shiah, F. K., and H. W. Ducklow. 1994a. Temperature and substrate regulation of bacterial abundance, production and specific growth rate in Chesapeake Bay, USA. Mar. Ecol. Prog. Ser. 103: 297-308, doi:10.3354/meps103297

, AND - 1994b. Temperature regulation of heterotrophic bacterioplankton abundance, production, and specific growth-rate in Chesapeake Bay. Limnol. Oceanogr. 39: 1243-1258, doi:10.4319/lo.1994.39.6.1243

Smith, D. C., ANd F. Azam. 1992. A simple, economical method for measuring bacterial protein synthesis rates in sea water using 3H-leucine. Mar. Microb. Food Webs 6: 107-114.

Sмiтh, E. M. 1998. Coherence of microbial respiration rate and cell-specific bacterial activity in a coastal planktonic community. Aquat. Microb. Ecol. 16: 27-35, doi:10.3354/ame016027

—, and P. A. Del Giorgio. 2003. Low fractions of active bacteria in natural aquatic communities? Aquat. Microb. Ecol. 31: 203-208, doi:10.3354/ame031203

SøndergaArd, M., and M. Danielsen. 2001. Active bacteria (CTC+) in temperate lakes: Temporal and cross-system variations. J. Plankt. Res. 23: 1195-1206, doi:10.1093/plankt/23.11.1195

StarosciK, A. M., AND D. C. Smith. 2004. Seasonal patterns in bacterioplankton abundance and production in Narragansett Bay, Rhode Island, USA. Aquat. Microb. Ecol. 35: 275-282, doi:10.3354/ame035275

Steinberg, D. K., C. A. Carlson, N. R. Bates, R. J. Johnson, A. F. Michaels, AND A. H. KNAP. 2001. Overview of the US JGOFS Bermuda Atlantic Time-series Study (BATS): A decade-scale look at ocean biology and biogeochemistry. Deep-Sea Res. II 48: 1405-1447, doi:10.1016/S0967-0645(00)00148-X
Teira, E., S. Martínez-Garcia, C. Lønborg, and X. A. ÁlvarezSALGADO. 2009. Growth rates of different phylogenetic bacterioplankton groups in a coastal upwelling system. Environ. Microbiol. Rep. 1: 545-554, doi:10.1111/j.1758-2229.2009.00079.x

VAliela, I., AND others. 1992. Couplings of watersheds and coastal waters: Sources and consequences of nutrient enrichment in Waquoit Bay, Massachusetts. Estuaries 15: 443-457.

Vaqué, D., E. O. Casamayor, and J. M. Gasol. 2001. Dynamics of whole community bacterial production and grazing losses in seawater incubations as related to the changes in the proportions of bacteria with different DNA content. Aquat. Microb. Ecol. 25: 163-177, doi:10.3354/ame025163

Wang, Y. Y., F. Hammes, N. Boon, M. Chami, and T. Egli. 2009. Isolation and characterization of low nucleic acid (LNA)content bacteria. ISME J. 3: 889-902, doi:10.1038/ismej.2009.46

White, P. A., J. KalfF, J. B. Rasmussen, and J. M. Gasol. 1991. The effect of temperature and algal biomass on bacterial production and specific growth rate in freshwater and marine habitats. Microb. Ecol. 21: 99-118, doi:10.1007/BF02539147

Wright, R. T., AND R. B. Coffin. 1983. Planktonic bacteria in estuaries and coastal waters of northern Massachusetts: Spatial and temporal distribution. Mar. Ecol. Prog. Ser. 11: 205-216, doi:10.3354/meps011205

YAGer, P. L., AND OTHERs. 2001. Dynamic bacterial and viral response to an algal bloom at subzero temperatures. Limnol. Oceanogr. 46: 790-801, doi:10.4319/lo.2001.46.4.0790

Yokokawa, T., And T. Nagata. 2005. Growth and grazing mortality rates of phylogenetic groups of bacterioplankton in coastal marine environments. Appl. Environ. Microbiol. 71: 6799-6807, doi:10.1128/AEM.71.11.6799-6807.2005

\section{, —, M. T. Cottrell, and D. L. Kirchman. 2004.} Growth rate of the major phylogenetic bacterial groups in the Delaware estuary. Limnol. Oceanogr. 49: 1620-1629, doi:10.4319/lo.2004.49.5.1620

Zöllner, E., H. G. Hoppe, U. Sommer, and K. Jürgens. 2009. Effect of zooplankton-mediated trophic cascades on marine microbial food web components (bacteria, nanoflagellates, ciliates). Limnol. Oceanogr. 54: 262-275.

Zubkov, M. V., J. I. Allen, And B. M. Fuchs. 2004. Coexistence of dominant groups in marine bacterioplankton community - a combination of experimental and modelling approaches. J. Mar. Biol. Ass. UK 84: 519-529, doi:10. 1017/S002531540400952Xh

, B. M. Fuchs, P. H. Burkill, and R. Amann. 2001. Comparison of cellular and biomass specific activities of dominant bacterioplankton groups in stratified waters of the Celtic Sea. Appl. Environ. Microbiol. 67: 5210-5218, doi:10. 1128/AEM.67.11.5210-5218.2001

Associate editor: Mikhail V. Zubkov

Received: 13 May 2010 Amended: 24 September 2010 Accepted: 26 September 2010 